\title{
POTENSI RERESIK SUMUR PITU SEBAGAI PENDEKATAN KEARIFAN LOKAL DAN BUDAYA PADA PEMBELAJARAN BIOLOGI
}

\author{
Fajar Adinugraha \\ Program Studi Pendidikan Biologi, Universitas Kristen Indonesia \\ e-mail: fadinugraha@yahoo.co.id, fajar.adinugraha@uki.ac.id
}

\begin{abstract}
ABSTRAK
Artikel ini bertujuan untuk deskripsi Reresik Sumur Pitu Kajian Kearifan Lokal dan Budaya Reresik Sumur Pitu dan Potensi Reresik Sumur Pitu sebagai Pendekatan Kearifan Lokal dan Budaya pada Pelajaran Biologi. Metode penelitian menggunakan kajian literatur dan observasi lapangan di Kelurahan Cangkrep Kidul, Kecamatan Purworejo, Kabupaten Purworejo. Reresik Sumur Pitu merupakan acara untuk mengajak membersihkan sumur (sumber mata air) yang disebut juga Sumur Kemloko. Pembahasan yang dilakukan, meliputi deskripsi Reresik Sumur Pitu, Kajian etnobiologi, Kajian etnopedagogi, dan Implementasinya dalam Pembelajaran Biologi. Kajian secara etnobiologi dan etnopedagogi yang sudah dilakukan menyimpulkan bahwa Reresik Sumur Pitu berpotensi sebagai Pendekatan Kearifan Lokal dan Budaya pada pelajaran Biologi. Topik yang bisa diintegrasikan dengan Reresik Sumur Pitu antara lain Biologi sebagai Ilmu Pengetahuan, Keanekaragaman Hayati, Kingdom Plantae, Kingdom Animalia, Ekosistem dan Isu Lingkungan. Reresik Sumur Pitu berpotensi sebagai sumber belajar karena memuat kompetensi yang disarankan oleh Kurikulum 2013, yaitu kompetensi sikap spiritual, kompetensi sikap sosial, kompetensi pengetahuan, dan kompetensi keterampilan. Selain menambah pengetahuan, pendekatan kearifan lokal dan budaya berpotensi sebagai penumbuh rasa nasionalisme dan bangga akan potensi daerahnya.
\end{abstract}

Kata Kunci: etnobiologi, etnopedagogi, kearifan local, Reresik Sumur Pitu

\section{PENDAHULUAN}

Biologi merupakan salah satu mata pelajaran peminatan pada Kurikulum 2013. Biologi mulai diperkenalkan secara langsung pada jenjang SMA/MA atau bahkan SMK dengan keahlian khusus. Namun, pada dasarnya di jenjang SMP, siswa sudah mempelajarinya dalam IPA Terpadu, di mana IPA Terpadu memuat 3 (tiga) ilmu utama, yaitu Fisika, Biologi, dan Kimia. Lebih jauh lagi, sebenarnya ketika di jenjang SD Biologi juga sudah diperkenalkan tetapi dengan cara yang sederhana.

Biologi pada jenjang SMA/MA berkaitan dengan topik, yaitu keanekaragaman hayati, ekologi, isu lingkungan, biologi sel dan molekuler, anatomi fisiologi tumbuhan, anatomi fisiologi manusia, genetika, evolusi, dan bioteknologi. Namun, pada artikel ini 
hanya dibatasi pada pembelajaran di Kelas $X$, yaitu secara khusus pada bahasan keanekaragaman hayati, ekologi, dan isu lingkungan.

Pada dasarnya, bahasan topik Biologi di Kelas $\mathrm{X}$ ini dapat dihubungkan dengan lingkungan di sekitar siswa bersekolah.Keadaaan lingkungan sekitar dapat digunakan sebagai pendekatan dalam pembelajaran. Hal ini dapat dilakukan dengan mengamati, mengidentifikasi, dan menganalisis keanekaragaman hayati, ekologi, dan lingkungan sekitar. Salah satu pendekatan yang berkaitan dengan lingkungan sekitar adalah Pendekatan Kearifan Lokal dan Budaya.

Kearifan lokal atau local wisdom dapat diartikan sebagai kearifan setempat yang merupakan gagasan/pengetahuan masyarakat setempat di mana memiliki nilai/sifat bijaksana (arif) dan tertanam dalam diri masyarakat dan diikuti oleh masyarakat tersebut (Kristiyanto, 2017:163). Menurut Kartawinata dalam Nasruddin et al, (2011: ix), jika ditinjau dari konsep antropologi, kearifan lokal dikenal sebagai pengetahuan setempat (indigenous or local knowledge) atau dapat dikatakan sebagai kecerdasan setempat (local genius), yang menjadi dasar dari sebuah kebudayaan (cultural identity). Oleh karena itu, dalam tulisan ini kearifan lokal yang dimaksud adalah gagasan baik tertulis atau tidak tertulis yang dimiliki oleh masyarakat tertentu di mana gagasan tersebut memiliki nilai-nilai sebagai dasar munculnya kebudayaan di daerah tersebut.

Kearifan lokal tidak dapat dipisahkan dari kebudayaan. Kebudayaan memiliki kata dasar budaya yang dapat diartikan sebagai suatu proses dari krida, cipta, rasa, dan karsa yang lahir di masyarakat (Kurnianto, 2016:1). Budaya juga dapat dikatakan sebagai cara hidup masyarakat yang berupa warisan turun temurun dari generasi ke generasi berikutnya (Maridi, 2015:22). Budaya merupakan produk baik bersifat fisik maupun non fisik yang diwariskan secara turun temurun menggunakan tradisi lisan ataupun tulisan.

Pendekatan Kearifan Lokal dan Budaya ini menjadi penting karena batas-batas informasi sangat mudah diakses oleh masyarakat terutama siswa yang merupakan generasi Z (lahir pada tahun 1995 sampai 2010) dan generasi alfa (lahir setelah tahun 2010). Informasi yang bisa diakses secara cepat memberikan dampak positif sekaligus 
negatif. Selanjutnya, informasi negatif yang tidak sesuai dengan karakter bangsa akan mempengaruhi karakter siswa menjadi buruk. Karakter buruk di mana beberapa siswa menganggap kearifan lokal dan budaya merupakan hal kuno, lambat laun akan mengikis rasa memiliki bangsa sendiri. Apabila ini dibiarkan, maka kemungkinan bangsa Indonesia akan kehilangan jati dirinya.

Pengaruh dari luar negeri baik budaya dan informasi bukanlah sesuatu yang perlu ditakuti. Pembatasan informasi justru akan membuat siswa tidak berpikir kritis. Salah satu cara untuk mengatasi hal ini adalah dengan gerakan literasi. Pendekatan pembelajaran yang bisa digunakan untuk mendukung literasi dengan tetap berpegang pada jati diri bangsa adalah Pendekatan Kearifan Lokal dan Budaya.

Pendekatan Kearifan Lokal dan Budaya merupakan pendekatan pembelajaran yang mengintegrasikan nilai kearifan lokal dan budaya di lingkungan tempat tinggal siswa. Kearifan lokal dan budaya yang dimaksud adalah yang berkaitan dengan mata pelajaran Biologi. Kajian-kajian yang dilakukan dapat menggunakan kajian yaitu etnobiologi. Menurut Iskandar (2016: 27), etnobiologi merupakan bentuk kajian ilmiah mengenai pengetahuan penduduk yang berhubungan dengan biologi, antara lain tumbuhan (botani), hewan (zoologi), dan lingkungan alam (ekologi).

Selanjutnya, kajian etnopedagogi juga dapat dilakukan dalam pendekatan kearifan lokal dan budaya. Menurut Kurniawan \& Survani (2017:16), etnopedagogi merupakan sebuah praktik pendidikan berbasis kearifan lokal yang mencakup aspek pengobatan, seni bela diri, lingkungan hidup, pertanian, ekonomi, pemerintahan, sistem penanggalan, dan lain-lain. Selanjutnya, menurut Oktavianti \& Ratnasari (2018:149-153), etnopedagogi merupakan bentuk aktualisasi pembelajaran di mana menekankan nilai-nilai kearifan lokal.Oleh karena itu, dapat disintesiskan bawah Pendekatan Kearifan Lokal dan Budaya pada pelajaran Biologi adalah sebuah bentuk pendekatan pembelajaran yang mengintegrasikan kearifan lokal budaya dan setempat dengan menggunakan kajian etnobiologi dan etnopedagogi.

Kearifan lokal dan budaya setempat banyak ditemukan nilai-nilai karakter yang bisa menjadi senjata ampuh melawan pengaruh karakter negatif (ranah sikap dan spiritual). Kajian etnobiologi dapat memberikan pengetahuan mengenai 
keanekaragaman hayati (ranah pengetahuan) dan aspek kegunaan termasuk proses pembuatan dan cara penggunaan (ranah keterampilan). Oleh karena itu, pendekatan ini selaras dengan Kurikulum 2013, di mana kemampuan hasil belajar siswa bukan hanya dari dilihat dari kompetensi pengetahuan saja tetapi dari kompetensi sikap spiritual, sikap sosial, dan kompetensi keterampilan.

Kearifan lokal dan budaya yang ditulis dalam artikel ini adalah Reresik Sumur Pitu. Reresik Sumur Pitu dalam Bahasa Indonesia, artinya pembersihan (reresik), sumur (sumur), tujuh (pitu). Jadi, ada sebuah kebiasaan masyarakat sekitar untuk menjaga dan melestatikan sumber mata air yang berjumlah tujuh di Kelurahan Cangkrep Kidul, Purworejo. Beberapa daerah juga memiliki prosesi adat yang hampir sama seperti reresik sumur. Namun, setiap daerah pasti punya latar belakang cerita yang berbeda. Oleh karena itu, artikel ini akan membahas, yaitudeskripsi Reresik Sumur Pitu, Kajian Kearifan Lokal dan Budaya Reresik Sumur Pitu dan Potensi Reresik Sumur Pitu sebagai Pendekatan Kearifan Lokal dan Budaya pada Pelajaran Biologi.

\section{METODE PENELITIAN}

Metode penelitian yang digunakan dalam penelitian ini adalah kajian pustaka dan observasi lapangan. Kajian pustaka yang digunakan adalah dengan sumber utama, yaitu Buku yang berjudul Kitab Reresik Sumur Pitu karangan Makhasin. Selain itu, digunakan sumber lain yang relevan. Observasi lapangan dilakukan dengan melalui pengamatan langsung di acara Reresik Reresik Sumur Pitu.

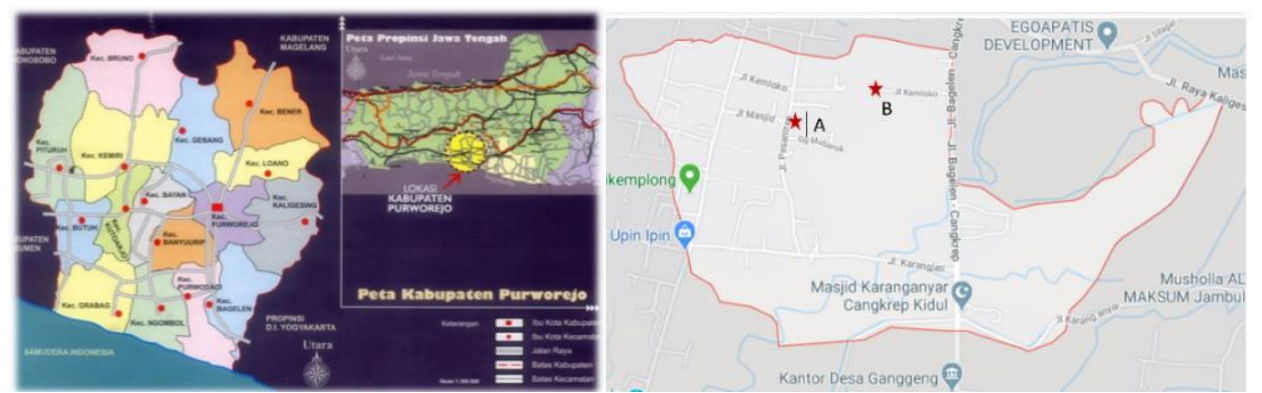

Gambar 1. Peta Kabupaten Purworejo (atas) dan Peta Kelurahan Cangkrep Kidul (bawah); dimana (A) adalah Kantor Kelurahan Cangkrep Kidul dan (B) adalah Sumur PituKemloko.

Sumber: Andriyatmoko (2017), https://pa-purworejo.go.id dan googlemap 
Lokasi observasi Reresik Sumur Pitu adalah Kelurahan Cangkrep Kidul, Kecamatan Purworejo, Kabupaten Purworejo. Peta disajikan pada Gambar 1. Waktu pelaksanaan observasi, yaitu Sabtu, 4 Agustus 2018 dari pukul 13.00-16.00.

Data dalam artikel ini berupa deskripsi kegiatan dan didukung oleh dokumentasi baik berupa foto dan video. Selanjutnya, data dianalisis dengan deskripsi kualitatif.

\section{HASIL PENELITIAN DAN PEMBAHASAN}

Artikel ini memuat 3 (tiga) topik, yaitu deskripsi Reresik Sumur Pitu Kajian Kearifan Lokal dan Budaya Reresik Sumur Pitu dan Potensi Reresik Sumur Pitu sebagai Pendekatan Kearifan Lokal dan Budaya pada Pelajaran Biologi. Ketiga topik tersebut dijelaskan sebagai berikut.

\section{A. Deskripsi Reresik Reresik Sumur Pitu}

Kabupaten Purworejo merupakan kabupaten di Jawa Tengah dengan letak 109047'28" sampai 11008'20" BT serta 7032" dan 7054" LS. Kabupaten Purworejo berbatasan dengan Kabupaten Wonosobo dan Magelang (utara), Daerah Istimewa Yogyakarta (Timur), Samudra Hindia (Selatan), dan Kabupaten Kebumen (Timur). Kabupaten ini memiliki 16 kecamatan dan 494 desa/kelurahan. Luas wilayah Kabupaten Purworejo 103.481 ha, yang terdiri atas lahan pertanian (sawah dan bukan sawah), yaitu $84,18 \%$ dan lahan bukan pertanian $15,82 \%$ (http://si.disperakim.jatengprov.go.id/).

Kelurahan Cangkrep Kidul yang menjadi tempat penelitian merupakan kelurahan di Kecamatan Purworejo. Kelurahan ini dilalui jalan raya Cangkrep ke arah Bagelen dan Jogja. Jalan ini dilewati sungai bernama Sungai Mongo. Selain itu, ada akses jalan menuju ke arah Rumah Memorial WR Supratman di Somongari, Kaligesing. Kelurahan Cangkrep Kidul berbatasan dengan Desa Ganggeng (selatan), Kelurahan Cangkrep Lor (utara), dan Kelurahan Kedungsari (Barat) (Wikipedia, 2020).

Apabila dilihat dari peta satelit google maps (Gambar 2) maka dapat dilihat bahwa wilayahnya berupa lahan pertanian (hampir setengah lebih) dan lahan non 
pertanian. Mata pencaharian warga Cangkrep Kidul adalah petani (pemilik maupun buruh tani), pegawai negeri, wirausaha, dan sisanya jenis pekerjaan lainnya.

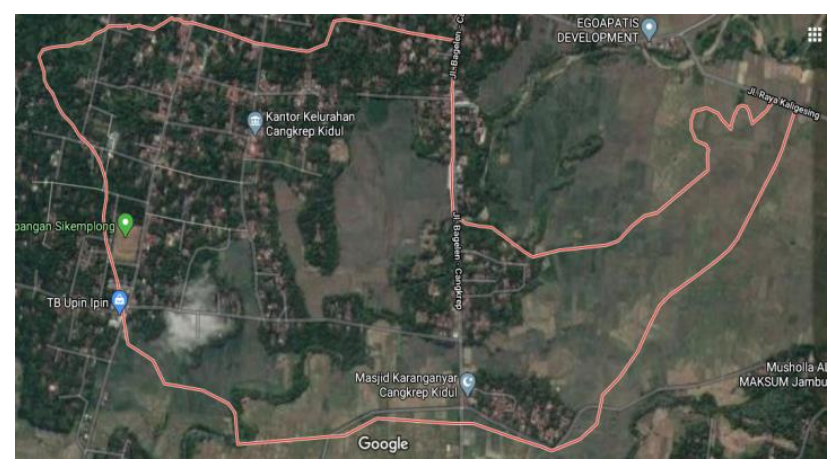

Gambar 2. Citra Satelit Kelurahan Cangkrep Kidul. Sumber:https://www.google.com/maps/place/Cangkrepkidul

Nama Cangkrep diduga dari kata "Pucang kerep", yang artinya banyaknya pohon pinang. Disebutkan pula bahwa pada masa Mataram, Kelurahan Cangkrep Kidul konon disebut Seket Kidul dengan penguasa pertama, yaitu Ki Pronogati yang memerintah sejak zaman Mataram hingga tahun 1890. Selanjutnya, terbentuk padukuhan pada masa Ahmad Syahid (1959-1986) yaitu sebanyak 7 (tujuh) padukuhan sekaligus sebagai simbol mata air Sumur Kemloko yang berjumlah 7 (tujuh) atau dikenal sebagai Reresik Sumur Pitu (Makhasin, 2018:2).

Reresik Sumur Pitu atau dikenal sebagai Sumur Kemloko ini menempati area $\pm 1000 \mathrm{~m}^{2}$. Sumur ini berupa sendang atau mata air. Ketujuh sumur tersebut diberi nama, antara lain sumur pancur, sumur buthek, sumur lanang, sumur wedok, sumur planangan, sumur pandansari 1 , dan sumur pandansari 2. Ketujuh sumur ini dianggap keramat oleh warga sekitar dengan beberapa kekhasan cerita mistis atau perisitwa yang melatarbelakangi penamaan sumur tersebut (Makhasin, 2018:6-7).

Reresik Sumur Pitu merupakan sebuah upacara yang diprakarsai oleh karang taruna setempat untuk mengangkat potensi alam dan budaya. Selain itu, Reresik Sumur Pitu sebagai ajakan untuk menyadarkan masyarakat dalam memelihara sumber mata air dengan memperhatikan pembangunan sekitarnya.Reresik Sumur Pitu (Kemloko) terdiri atas beberapa prosesi atau acara. Prosesi tersebut, antara lain 1) upacara pemberangkatan kirab; 2) upacara pengambilan air suci, penjamasan barong, 
dan perebutan tumpeng buah di Reresik Sumur Pitu; 3) upacara jamasan; 4) makan tumpeng; dan 5) pertunjukan jarang kepang. Penjelasan acara dijelaskan sebagai berikut dengan bantuan buku Kitab Reresik Sumur Pitu karangan Makhasin (2018) dan pengamatan langsung di lokasi (Gambar 3).

1. Upacara pemberangkatan kirab

Acara dimulai pukul 14.00 WIB. Pemberangkatan kirab di mulai dari halaman Kantor Kelurahan Cangkrep Kidul (Gambar 1.A). Kirab diawali dengan pertunjukan teatrikal anak-anak.Selanjutnya, dilakukan arak-arakan kirab dengan peserta kirab, antara lain (a) Empat prajurit putra; (b) Dalang, Harjito, Hadi Suprodjo, dan Joko Banendro; (c) Pembawa dupa; (d) Kidung Rinonce (para spiritualis yang berasal dari berbagai daerah); (e) Empat prajurit putri (Perguruan Trisula); (f) Lurah Cangkrep Kidul; (g) Duta pemuda pemudi (Bagus Roro Kabupaten Purworejo); (h) Hapsara Hapsari dan Tujuh Anak yang belum baligh; (i) Gunungan buah; (j) Drumband (MTs Maarif NU); (k) Perangkat Kelurahan; dan (I) Perwakilan warga dari 7 (tujuh) lingkungan di Cangkrep Kidul.

2. Upacara pengambilan air suci, penjamasan barong, dan perebutan gunungan buah

Arak-arakan kirab tiba di Reresik Sumur Pitu yang kemudian disambut dengan kelompok musik sholawatan. Hal ini menandakan bahwa lingkungan ini merupakan lingkungan dengan warga yang taat beragama dan sebagai ucapan syukur serta pujian kepada Tuhan. Selanjutnya, dilakukan pengambilan air suci di 7 (tujuh) sumur dengan diiringi oleh dalang. Setelah itu, dilakukan penjamasan barong dan perlengkapan jaran kepang. Acara selanjutnya adalah memecah kendi, perebutan tumpeng gunungan, dan dilanjutkan arak-arakan ke lokasi penjamasan.

3. Upacara jamasan

Penjamasan dilakukan di Laboratorium Alam Komunitas Teater Purworejo (LA KTP). Peserta kirab yang dijamas adalah Lurah Cangkrep Kidul, Para Perangkat Kelurahan, Ketua Karang Taruna, dan beberapa peserta kirab lainnya. Penjasmasan diiringi dengan Tembang Sekar Asmarandana PI 6 diteruskan gending Santi Mulya.

4. Makan tumpeng 
Akhir kirab dilakukan acara makan tumpeng bersama. Makan tumpeng bersama ini dilakukan di halaman balai Kelurahan Cangkrep Kidul dengan dilakukan tahlil dan doa.
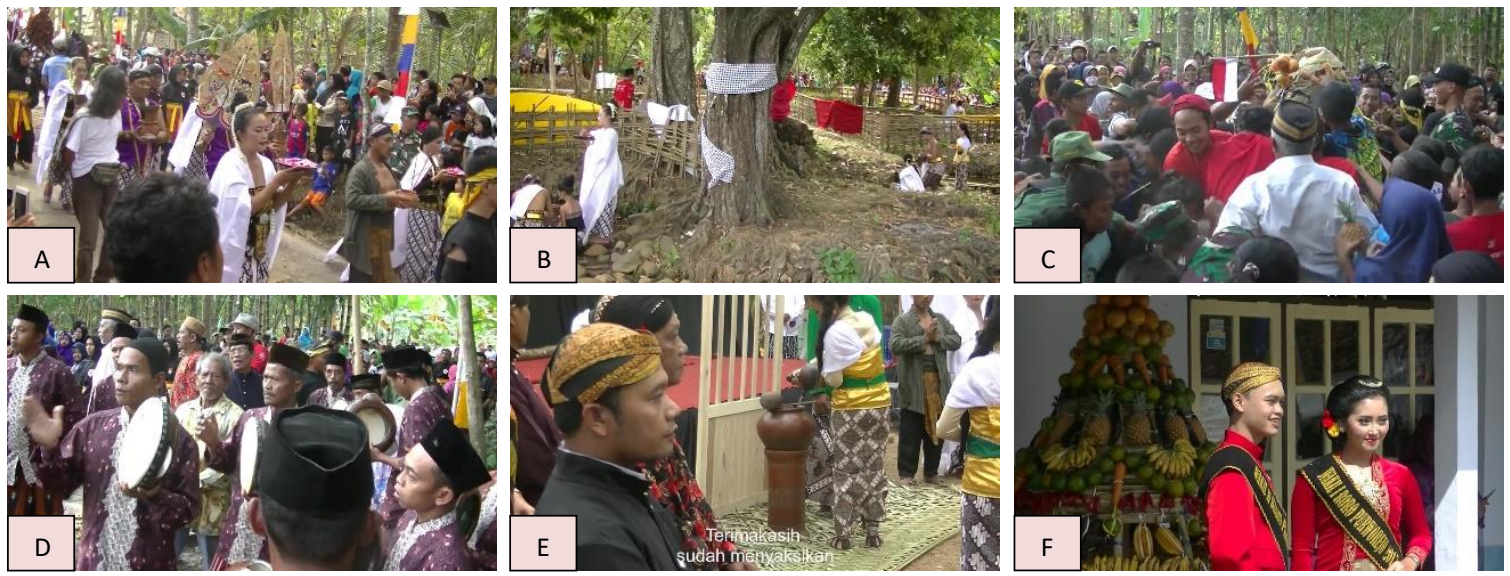

Gambar 3. Beberapa Kegiatan Kirab Reresik Sumur Pitu. (A) Peserta kirab, (B) Pengambilan air di mata air (sumur), (C) Berebut tumpeng buah (gunungan), (D) Pemain sholawatan, (E) Upacara jamasan, dan (F) Peserta kirab berfoto di depan tumpeng buah (gunungan)

Sumber: Adinugraha (2018)

\section{Pertunjukan jarang kepang}

Jarang kepang merupakan salah satu kesenian tradisional dari Kabupaten Purworejo. Kesenian ini terdiri atas penari (biasanya laki-laki) yang menunggangi semacam kuda buatan yang terbuat dari anyaman bambu. Selain itu, terdapat pula barong yang dimaikan dalam kostum seperti harimau. Kesenian ini diiringi dengan alat musik gamelan lengkap dengan penyanyinya. Dokumentasi Kirab Reresik Sumur Pitu dalam bentuk video dapat dilihat pada link Youtube https://youtu.be/2W5wIV5AQXY

\section{B. Kajian Kearifan Lokal dan Budaya Reresik Sumur Pitu}

\section{Etnobiologi pada acara Reresik Sumur Pitu}

Etnobiologi yang dimaksud dalam artikel ini dibatasi pada pemanfataan organisme, yaitu species dan bagian yang digunakan dalam upacara. Pemanfaatan hewan yang digunakan dalam upacara ini adalah kuda (Equus caballus) yang digunakan oleh peserta kirab menuju Sumur Pitu. Selain itu, saat acara makan tumpeng bersama, terdapat hewan ternak yang digunakan sebagai tambahan lauk pada nasi tumpeng seperti ayam (Gallus gallus). Pemanfaatan tumbuhan lebih dominan digunakan dalam 
upacara ini. Pemanfaatan tumbuhan yang dijelaskan pada artikel ini adalah ubarampe (sarana) yang digunakan oleh peserta kirab. Tumbuhan dan pemanfaatannya disajikan pada Tabel 1.

Tabel 1. Species pada Tumbuhan dan Pemanfaatannya pada Upacara Reresik Sumur Pitu

\begin{tabular}{lllll}
\hline No & \multicolumn{1}{c}{ Nama lokal } & \multicolumn{1}{c}{ Nama species } & Kelompok* & $\begin{array}{c}\text { Bagian yang } \\
\text { digunakan }\end{array}$ \\
\hline $\mathbf{1}$ & Kacang panjang & Vigna unguiculata & Eudicots & Buah \\
$\mathbf{2}$ & Jeruk & Citrus $x$ sinensis & Eudicots & Buah \\
$\mathbf{3}$ & Salak & Salacca zalacca & Monocots & Buah \\
$\mathbf{4}$ & Pisang & Musa acuminata & Monocots & Buah \\
$\mathbf{5}$ & Semangka & Citrullus lanatus & Eudicots & Buah \\
$\mathbf{6}$ & Belimbing & Averrhoa carambola $\mathrm{L}$. & Eudicots & Buah \\
$\mathbf{7}$ & Cabai & Capsicum annuum L. & Eudicots & Buah \\
$\mathbf{8}$ & Wortel & Daucus carota & Eudicots & Umbi \\
$\mathbf{9}$ & Terung/terong & Solanum melongena & Eudicots & Buah \\
$\mathbf{1 0}$ & Nanas/nenas & Ananas comosus (L.) Merr. & Monocots & Buah \\
$\mathbf{1 1}$ & Apel & Malus domestica Borkh. & Eudicots & Buah \\
$\mathbf{1 2}$ & Mawar & Rosa sp. & Eudicots & Bunga \\
$\mathbf{1 3}$ & Melati & Jasminum sambac & Eudicots & Bunga \\
$\mathbf{1 4}$ & Sedap malam & Polianthes tuberosa L. & Monocots & Bunga \\
$\mathbf{1 5}$ & Bawang merah & Allium cepa var. aggregatum L. & Monocots & Umbi \\
$\mathbf{1 6}$ & Bambu & Bambusa sp. & Monocots & Batang \\
\hline
\end{tabular}

*Kelompok yang digunakan menggunakan nama kelompok yang disesuaikan dengan materi Biologi Kelas X SMA/MA

Pengamatan dilakukan terhadap tumpeng buah yang berupa gunungan berisi hasil bumi (buah dan umbi) yang diletakkan dan diikat pada anyaman bambu. Selain itu, pengamatan juga dilakukan pada atribut yang dikenakan oleh peserta kirab. Bagian dari tumbuhan yang digunakan, antara lain buah (sebagian besar sebagai pelengkap gunungan), bunga, umbi, dan batang.

Selanjutnya, tumbuhan tersebut dikelompokkan ke dalam kelompok eudicots dan monocots. Pengelompokkan ini didasarkan pada buku Urry et al. (2017) dan disesuaikan dengan materi Biologi kelas X. Species yang ditemukan termasuk dalam kelompok Angiospermae. Kemudian, species tersebut dikelompokkan ke dalam kelompok, yaitu Amborella, Water lilies, Star Anise, Magnoliids, Monocots, dan Eudicots. Pengelompokkan species disesuaikan dengan ke enam kelompok tersebut, tetapi lebih ditekankan pada kelompok monocots (monokotil) dan kelompok eudicots (dikotil). Pengelompokkan tersebut dapat dilihat pada Tabel 1. 
Selain acara kirab, yang menjadi perhatian adalah keberadaan Sumur Pitu (sumur Kemloko) tersebut. Keunikan dari sumur (mata air) tersebut adalah tidak mengering walau daerah tersebut sedang mengalami musim kemarau. Hal ini dapat dilihat ketika puncak acara tersebut berlangsung, yaitu pada Sabtu, 4 Agustus 2018.

Apabila diamati, sumber mata air tersebut berada di bawah pohon-pohon besar yang dianggap mistis oleh beberapa orang (Gambar 3.B). Sumber mata air tersebut berada tepat disekitar atau di bawah pohon Gayam [Inocarpus fagifer (Parkinson ex Zollinger) Fosberg]. Species dari kelompokeudicots ini mampu menjaga sumber mata air di daerah tersebut. Masyarakat sekitar beranggapan bahwa pohon Gayam ini perlu terus dijaga karena berfungsi sebagai pelindung mata air.

Menurut Wawo et al. (2011:140-151), pohon Gayam yang banyak ditemukan di daerah lembab (tanah liat berpasir) ini juga memiliki kegunaan, seperti bahan pangan, pakan ternak, kayu bakar, benteng kali, pestisida herbal, serta tempat hidup burung hantu dan kelelawar. Senada dengan hal ini, Tetelay et al. (2011) mengatakan bahwa Gayam dapat digunakan sebagai bahan pangan alternatif dengan cara memakan buah yang sudah direbus dan membuat keripik Gayam.

\section{Etnopedagogi pada acara Reresik Sumur Pitu}

Pedagogi merupakan salah satu kompetensi yang harus dimiliki oleh guru termasuk guru Biologi. Menurut Hiryanto (2017:65), pedagogi berasal dari Bahasa Yunani dan dapat diartikan secara harfiah, yaitu memimpin anak. Pedagogi juga dapat bermakna mengajari anak (Bahasa Latin). Dalam Bahasa Inggris, istilah ini digunakan pada teori pengajaran terutama bagi guru untuk dapat memahami bahan ajar, mengenal siswa, dan menentukan cara pengajarannya. Etno dalam artikel ini berarti yang berkaitan dengan kearifan lokal dan budaya. Oleh karena itu, etnopedagogi yang dimaksud adalah cara mendidik siswa (anak) dengan mengintegrasikan nilai-nilai kearifan lokal dan budaya setempat.

Etnopedagogi juga dapat berarti pendidikan untuk mempelajari budaya dari berbagai bidang (Sari \& Ganes Gunansyah, 2018:1769), termasuk di dalamnya nilainilai, nasihat, filosofi hidup oleh berbagai etnik dan suku (Hak, 2019: 279-296), yang juga merupakan suatu bentuk aktualisasi pembelajaran berbasis kearifan lokal 
(Oktavianti \& Yuni Ratnasari, 2018: 150-154). Oleh karena itu, etnopedagogi juga dapat diartikan sebagai pengintegrasian nilai-nilai kearifan lokal dan budaya dalam pembelajaran yang dapat ditularkan oleh guru kepada siswa termasuk di dalamnya aspek pengetahuan, keterampilan, dan sikap.

Peran guru menjadi sangat penting dalam menginformasikan sebuah kearifan lokal dan budaya kepada siswa. Hal ini penting agar tidak terjadi kesalahpahaman nilai yang ada di kearifan lokal dan budaya setempat. Oleh karena itu, guru juga harus mau membuka diri untuk menerima kearifan lokal dan budaya di tempat di mana guru dan siswa tinggal.

Berdasarkan Permendikbud Nomor 21 tahun 2016 tentang Standar Isi Pendidikan Dasar dan Menengah, di mana terdapat 4 (empat) kompetensi yang haru dimiliki oleh siswa, antara lain sikap spiritual, sikap sosial, pengetahuan dan keterampilan. Kompetensi pengetahuan dan keterampilan sudah dibahas pada poin B.1 yaitu kajian etnobiologi. Pada sub topik etnopedagogi ini akan meninjau dari segi nilai-nilai yang dapat diambil dari Reresik Sumur Pitu. Nilai-nilai tersebut berupa sikap spiritual dan sikap sosial yang disajikan pada Tabel 2.

Tabel 2. Nilai Sikap Spiritual dan Sikap Sosial pada Reresik Sumur Pitu*

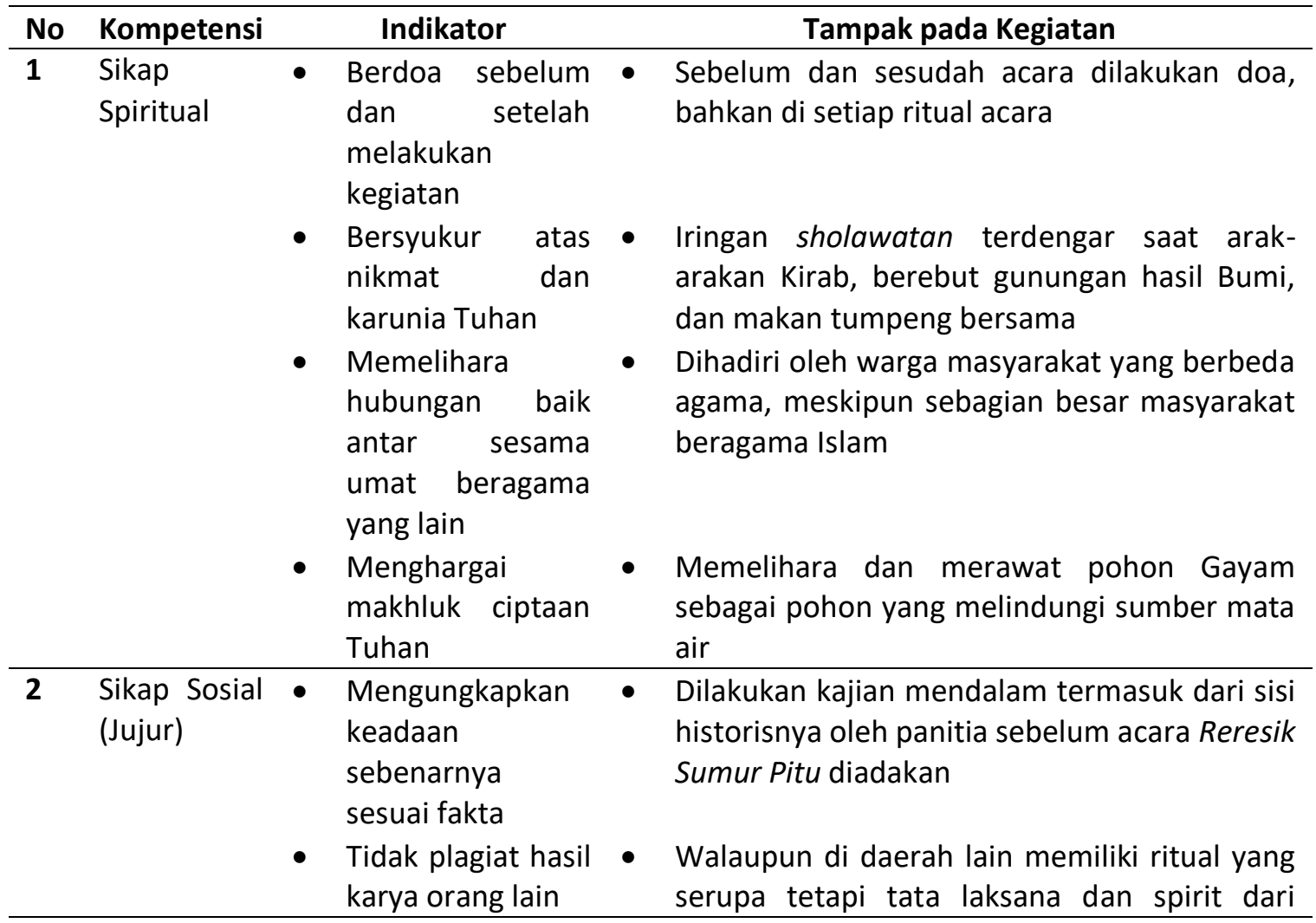




\begin{tabular}{|c|c|c|c|}
\hline No & Kompetensi & Indikator & Tampak pada Kegiatan \\
\hline & & & $\begin{array}{l}\text { acara Reresik Sumur Pitu pasti berbeda dari } \\
\text { yang ritual yang serupa }\end{array}$ \\
\hline 3 & $\begin{array}{l}\text { Sikap Sosial } \\
\text { (Disiplin) }\end{array}$ & $\begin{array}{l}\text { - Tertib dalam } \\
\text { melakukan } \\
\text { kegiatan }\end{array}$ & $\begin{array}{l}\text { - Acara berlangsung tanpa halangan atau } \\
\text { kekacauan. Peserta baik petugas dan warga } \\
\text { dengan tertib melihat jalannya acara. } \\
\text { - Berebut gunungan bukanlah menunjukkan } \\
\text { sesuatu yang tidak tertib. Namun, sebagai } \\
\text { bentuk sukacita warga atas nikmat dari } \\
\text { Tuhan. Semua orang berbaur menjadi satu } \\
\text { tanpa memandang suku dan agama. }\end{array}$ \\
\hline \multirow[t]{5}{*}{4} & $\begin{array}{l}\text { Sikap Sosial } \\
\text { (Santun) }\end{array}$ & 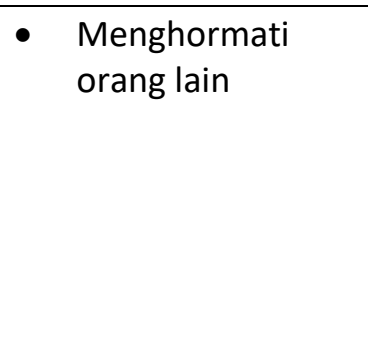 & $\begin{array}{l}\text { - Acara tersebut terselenggara juga karena } \\
\text { nasihat dari orang yang dituakan di daerah } \\
\text { tersebut. Panitia yang berbaur antara tua dan } \\
\text { muda menjadi bukti saling menghormat } \\
\text { antar generasi. Termasuk mengundang } \\
\text { pejabat daerah sebagai wujud menghormati } \\
\text { pimpinan. }\end{array}$ \\
\hline & & $\begin{array}{l}\text { - Menempatkan } \\
\text { diri dalam bicara }\end{array}$ & $\begin{array}{l}\text { - Acara dilangsungkan menggunakan Bahasa } \\
\text { Jawa di mana Bahasa Jawa memiliki tingkatan } \\
\text { yang mewajibkan orang untuk mengetahui } \\
\text { jenis Bahasa Jawa yang digunakan (ngoko, } \\
\text { krama madya, krama inggil, atau Jawa kuno) }\end{array}$ \\
\hline & & $\begin{array}{l}\text { - Mengucapkan } \\
\text { terimakasih }\end{array}$ & $\begin{array}{l}\text { - Setiap akhir kegiatan selalu diucapkan } \\
\text { ungkapan rasa terimakasih kepada pihak yang } \\
\text { membantu dan meramaikan acara. }\end{array}$ \\
\hline & & $\begin{array}{l}\text { - Meminta izin jika } \\
\text { ada keperluan }\end{array}$ & $\begin{array}{l}\text { - Acara berlangsung dengan izin pejabat dan } \\
\text { keamanan setempat dengan dibuktikan } \\
\text { adanya personil keamanan. }\end{array}$ \\
\hline & & & $\begin{array}{l}\text { - Meminta izin juga dilakukan kepada sesepuh } \\
\text { dan makhluk gaib yang ada di sekitar Reresik } \\
\text { Sumur Pitu. Hal ini juga menjadi pelajaran } \\
\text { agar masyarakat tidak semena-mena atau } \\
\text { bertindak tidak terpuji di tempat yang baru. } \\
\text { Beberapa orang percaya bahwa di dunia ini } \\
\text { terdapat makhluk gaib yang tidak semua } \\
\text { orang dapat melihatnya. Oleh karena itu, } \\
\text { sebaiknya kita menghormati sesama } \\
\text { penghuni Bumi bukan berarti menyembah } \\
\text { makhluk gaib tersebut. }\end{array}$ \\
\hline \multirow[t]{2}{*}{5} & $\begin{array}{l}\text { Sikap Sosial } \\
\text { (Peduli) }\end{array}$ & $\begin{array}{l}\text { - Membantu orang } \\
\text { dalam melakukan } \\
\text { kegiatan }\end{array}$ & $\begin{array}{l}\text { - Acara tersebut terlaksana karena ada } \\
\text { kerjasama, gotong royong, toleransi, dan } \\
\text { kedamaian antara panitia dan warga } \\
\text { setempat sehingga bisa berjalan dengan } \\
\text { lancar. }\end{array}$ \\
\hline & & $\begin{array}{l}\text { - Peduli terhadap } \\
\text { lingkungan }\end{array}$ & $\begin{array}{l}\text { - Pelaksanaan kirab Reresik Sumur Pitu menjadi } \\
\text { tanda bahwa warga sekitar peduli terhadap } \\
\text { kelestarian dan keberadaan sumber mata air }\end{array}$ \\
\hline
\end{tabular}




\begin{tabular}{|c|c|c|c|}
\hline No & Kompetensi & Indikator & Tampak pada Kegiatan \\
\hline & & & $\begin{array}{l}\text { (sumur) yang sudah ada sejak zaman dahulu. } \\
\text { Pelestarian tanaman Gayam di sekitar mata } \\
\text { air menjadi bukti nyata kepedulian warga }\end{array}$ \\
\hline 6 & $\begin{array}{l}\text { Sikap Sosial } \\
\text { (Tanggung } \\
\text { jawab) }\end{array}$ & $\begin{array}{l}\text { - Melaksanakan } \\
\text { tugas sesuai jobs } \\
\text { description } \\
\text { - Berani } \\
\text { mengambil risiko } \\
\text { atas hal yang } \\
\text { dilakukan }\end{array}$ & $\begin{array}{l}\text { - Setiap peserta baik panitia atau warga } \\
\text { mengambil peran sesuai tugas masing- } \\
\text { masing. Hal ini terlihat dari pembagian peran } \\
\text { seperti dijelaskan di subtopic A.1. } \\
\text { - Acara ini dikemas menjadi acara kebudayaan } \\
\text { desa yang baru pertama diadakan. Hal ini } \\
\text { menunjukkan bahwa panitia dan warga } \\
\text { sekitar berani mengambil risiko terhadap } \\
\text { keberhasilan suatu acara. Acara tersebut juga } \\
\text { mendobrak stigma terhadap kesan angker } \\
\text { Reresik Sumur Pitu yang sebenarnya warisan } \\
\text { yang perlu dilestarikan. }\end{array}$ \\
\hline 7 & $\begin{array}{l}\text { Sikap Sosial } \\
\text { (Responsif) }\end{array}$ & $\begin{array}{l}\text { - Berpikir dan } \\
\text { berwawasan } \\
\text { maju }\end{array}$ & $\begin{array}{l}\text { - Setiap peserta baik panitia atau warga ikut } \\
\text { aktif dalam acara tersebut. Meskipun hanya } \\
\text { sebagai penonton, tetapi acara tersebut } \\
\text { masih ramai hingga acara selesai. Hal ini } \\
\text { membuktikan bahwa warga antusias } \\
\text { terhadap acara tersebut. } \\
\text { - Pengemasan kearifan lokal dalam bentuk } \\
\text { kebudayaan seperti dilakukan oleh warga } \\
\text { Cangkrep Kidul merupakan bentuk dari cara } \\
\text { berpikir untuk kemajuan desa/kelurahan. }\end{array}$ \\
\hline 8 & $\begin{array}{l}\text { Sikap Sosial } \\
\text { (Pro aktif) }\end{array}$ & $\begin{array}{ll}\text { - } & \text { Inisiatif dalam } \\
\text { melakukan } \\
\text { kegiatan } \\
\text { - } \text { Mampu } \\
\text { membaca dan } \\
\text { memanfaatkan } \\
\text { peluang }\end{array}$ & $\begin{array}{l}\text { - Ide yang muncul dalam setiap kegiatan } \\
\text { merupakan wujud inisiatif dari warga } \\
\text { setempat bukan dari luar daerah } \\
\text { - Terangkatnya Reresik Sumur Pitu sebagai } \\
\text { agenda tahunan warga Cangkrep Kidul dapat } \\
\text { membuktikan bahwa warga desa mampu } \\
\text { membaca peluang potensi yang ada di } \\
\text { daerahnya. Hal ini bisa menginspirasi daerah } \\
\text { lain untuk terus berinovasi. }\end{array}$ \\
\hline
\end{tabular}

* diadaptasi dari Adinugraha (2019: 21-22)

\section{Potensi Reresik Sumur Pitu sebagai Pendekatan Kearifan Lokal dan Budaya pada Pelajaran Biologi}

Pemaparan pada uraian B dan C dapat menggambarkan bahwa Reresik Sumur

Pitu dapat berpotensi sebagai Pendekatan Kearifan Lokal dan Budaya pada pelajaran Biologi. Aspek yang dilihat dari Reresik Sumur Pitu bukan hanya dari kajian etnobiologi tetapi dari etnopedagogi. 
Pendekatan Kearifan Lokal dan Budaya ini dapat digunakan sebagai alternatif pendekatan pada pembelajaran Kurikulum 2013. Bahkan, apabila Kurikulum berganti pendekatan ini masih bisa digunakan. Hal ini karena pendekatan ini memiliki prinsipprinsip, antara lain student centered learning, joyful learning, meaningful learning, scientific learning, dan local wisdom and cultural learning (Adinugraha, 2018: 25).

Pembelajaran berbasis lingkungan sekitar akan membuat siswa merasa tidak asing dalam belajar Biologi. Pembelajaran akan menjadi lebih nyata jika sumber belajar dari materi lokal dapat dimanfaatkan dalam pembelajaran, seperti kearifan lokal, potensi lokal, dan permasalahan lokal (Pradietha et al.,2014: 117). Pembelajaran dengan mendayagunakan potensi lokal akan memberikan keunggulan, antara lain sebagai pembelajaran kontestual, pendayagunaan dan pelesatarian keunggulan lokal, serta mencetak generasi berkarakter (Mumpuni, 2013: 1-7).

Guru sebagai fasilitator dalam pembelajaran harus mengetahui terlebih dahulu kearifan lokal dan budaya di daerah sekitar sekolah. Hal ini sesuai dengan tulisan Kahar et al. (2018:13-16) yang mengatakan bahwa guru harus mampu dalam mengemas potensi lokal yang ada di sekitar lingkungan sekolah dan wajib diketahui oleh guru agar pembelajaran efisien dan efektif.

Dalam pembelajaran Biologi, guru harus mampu mengidentifikasi dan menganalisis Kompetensi Dasar Biologi SMA/MA yang sekiranya bisa diintegrasikan dengan Pendekatan Kearifan Lokal dan Budaya. Berdasarkan hasil analisis penulis, topik Biologi Kelas X yang bisa digunakan menggunakan Pendekatan Kearifan Lokal dan Budaya adalah sebagai berikut.

1. Biologi sebagai ilmu pengetahuan. Topik ini meliputi pemanfaatan Biologi dan karakteristik Biologi. Pada topik ini, siswa bisa diajak untuk melihat potensi lokal di daerah sekitar.

2. Klasifikasi organisme. Topik ini meliputi tata nama ilmiah dan sejarah klasifikasi. Pada topik ini, siswa bisa diajak untuk mengelompokkan atau mengklasifikasi organisme yang menjadi potensi daerah, seperti hewan atau tanaman yang menjadi potensi lokal. 
3. Keanekaragaman Hayati. Topik ini meliputi keanekaragaman hayati dan jenisnya serta pelestariannya. Pada topik ini, siswa bisa diajak untuk mengidentifikasi keanekaragaman hayati apa saja yang ada di sekitar dan pemanfaatannya.

4. Enam kingdom (Eubacteria, Archaebacteria, Protista, Fungi, Plantae, dan Animalia). Topik ini meliputi anggota dari 6 (enam) kingdom yang dibagi menjadi beberapa bab. Pada topik ini, siswa bisa diajak untuk mengamati dan menganalisis potensi organisme yang ada di daerah termasuk pemanfaatanya. Sebagai contoh, jamu atau obat-obatan yang dimanfaatkan untuk menjaga imunitas tubuh untuk melawan penyakit. Atau contoh lain, pemanfaatan hewan untuk upacara adat dan keagamaan.

5. Ekosistem dan Isu Lingkungan. Topik ini mengenai ekosistem dan komponennya serta isu lingkungan. Pada topik ini, siswa bisa diajak untuk melihat kearifan lokal dalam menjaga alam di daerah masing-masing.

Integrasi topik budaya ke dalam Biologi memang tidak lepas dari peran guru dan siswa. Guru dan siswa harus mau membuka diri untuk melihat potensi kearifan lokal dan budaya yang terdapat di daerah sekitar. Hal ini selain untuk menambah wawasan tentang materi Biologi, juga dapat meningkatkan rasa cinta tanah air. Dengan mengenal dan memahami bahwa pelestarian kearifan lokal dan budaya itu penting, maka akan menjaga keutuhan bangsa dan mempertahankan jati diri bangsa. Kearifan lokal dan budaya bukanlah sesuatu yang kuno, tetapi ternyata bisa dijadikan pedoman dalam menciptakan pengetahuan-pengetahuan baru tanpa menghilangkan nilai-nilai atau falsafah-falsafah yang diturunkan oleh nenek moyang terdahulu.

\section{KESIMPULAN}

Kajian secara etnobiologi dan etnopedagogi yang sudah dilakukan menyimpulkan bahwa Reresik Sumur Pitu berpotensi sebagai Pendekatan Kearifan Lokal dan Budaya pada pelajaran Biologi. Topik yang bisa diintegrasikan dengan Reresik Sumur Pitu antara lain Biologi sebagai Ilmu Pengetahuan, Keanekaragaman Hayati, Kingdom Plantae, Kingdom Animalia, Ekosistem dan Isu Lingkungan. Reresik Sumur Pitu berpotensi sebagai sumber belajar karena memuat kompetensi yang disarankan 
oleh Kurikulum 2013, yaitu kompetensi sikap spiritual, kompetensi sikap sosial, kompetensi pengetahuan, dan kompetensi keterampilan. Selain menambah pengetahuan, pendekatan kearifan lokal dan budaya berpotensi sebagai penumbuh rasa nasionalisme dan bangga akan potensi daerahnya.

\section{DAFTAR PUSTAKA}

Adinugraha, F. 2018. Tari dolalak sebagai bentuk pendekayan kearifan lokal dan budaya pada mata pelajaran Biologi. EDUKA Jurnal Pendidikan, Hukum, dan Bisnis, 4 (1): 23-39.

Adinugraha, F. 2019. Buku Guru: Biologi Kelas X SMA. Jakarta: Puskurbuk Kemdikbud.

Andriyatmoko, A.D. 2017. Wilayah Yurisdiksi Pengadilan Agama Purworejo. https://papurworejo.go.id/tentang-pengadian/profile-pengadilan/wilayah-yurisdiksi [diakses 07 Maret 2020, pukul 14.35 WIB].

Dinas Perumahan Rakyat dan Pemukiman. Profil Kondisi Geografis Kabupaten Purworejo. http://si.disperakim.jatengprov.go.id/umum/detail kondisi geo/27 [diakses 07 Maret 2020, pukul 20.10 WIB].

Hak, P. 2019. Etnopedagogik pada masyarakat Suku Muna, Tolaki, dan Bajo di Sulawesi Tenggara (strategi pengintegrasian kearifan lokal dalam pembelajaran sejarah untuk penguatan karakter siswa). Seminar Nasional Sejarak ke-4 Jurusan Pendidikan Sejarah Universitas Negeri Padang, 279-296.

Hiryanto, H. 2017. Pedagogi, andragogi, dan heutagogi serta implikasinya dalam pemberdayaan masyarakat. Dinamika Pendidikan, 22 (1): 65-71.

Iskandar, J. 2016. Etnobiologi dan keragaman budaya di Indonesia. Umbara: Indonesian Journal of Anthropology, 1 (1): 27-42.

Kahar, AP \& Kiki Damayanti. 2018. Pemanfaatan potensi lokal sebagai pondasi konstruktivisme guru Biologi Kabupaten Kubu Raya mewujudkan learning biology problem orientation. Al-khidmah, 1: 13-16.

Kristiyanto, E.N. 2017. Kedudukan kearifan lokal dan peranan masyarakat dalam penataan ruang di daerah. Jurnal Rechtsvinding: Media Pembinaan Hukum Nasional, 6 (2): 159-177.

Kurnianto, R. 2016. Kearifan lokal sebagai media komunikasi membangun peradaban unggul. Seminar Universitas Muhammadiyah Ponorogo, 1-11.

Kurniawan, I.S \& Rifki Survani. 2017. Integrasi etnopedagogi dalam mengembangkan model pembelajaran Biologi. Jurnal Konseling dan Pendidikan, 6 (1): 15-24. 
Makhasin, M. 2018. Kitab Reresik Sumur Pitu. Purworejo: Patria Publishing.

Maridi, M. 2015. Mengangkat budaya dan kearifan lokal dalam sistem konservasi Tanah dan Air. Proceeding Biology Education Conference, 20-39.

Mumpuni, K.E. 2013. Potensi pendidikan keunggulan lokal berbasi karakter dalam pembelajaran Biologi di Indonesia. Proceeding Seminar Nasional X Pendidikan Biologi FKIP UNS, 1-7.

Nasruddin, N., Siti Dloyana Kusumah, Bambang H.S Purwana, \& Ade M. Kartawinata. 2011. Buku kearifan lokal di tengah modernisasi. Jakarta: Kementerian Kebudayaan dan Pariwisata Republik Indonesia.

Oktavianti, I \& Yuni Ratnasari. 2018. Etnopedagogi dalam pembelajarn di Sekolah Dasar melalui media berbasis kearifan lokal. Jurnal Refleksi Edukatika, 8 (2): 150154.

Pradietha, E.T., Meilinda Meilinda \& Khoiron Nazip. 2014. Identifikasi materi lokal sebagai sumber belajar sains biologi SMP di Kabupaten Muara Enim. Jurnal Pembelajaran Biologi: Kajian Biologi dan Pembelajarannya, 1 (2): 115-126.

Sari, R.N \& Ganes Gunansyah. 2018. Batik gedhog Desa Kedungrejo-Tuban sebagai sumber belajar berbasi etnopedagodi di sekolah dasar. JPGSD, 6 (10): 1769-1780.

Tetelay, F.F \& Ludia Siahaya. 2018. Keberadaan dan potensi gayam (Inocarpus edulis) sebagai pohon penghasil pangan alternatif di Kabupaten Seram bagian barat Provinsi Maluku. Jurnal Hutan Pulau-Pulau Kecil, 1 (4): 310-320.

Urry, LA., Michael L. Chain, Steven A. Wasserman, Peter V. Minorsky \& Jane B. Reece. 2017. Biology: Campbell Eleventh Edition. New York: Pearson.

Wawo, A.H, Ninik Setyowati \& Ning Wikan Utami. 2011. Studi persebaran dan pemanfaatan gayam [(Inocarpus fagifer (Parkinson ex Zollinger)] di Daerah Istimewa Yogyakarta. Biosfera, 28 (3): 140-151.

Wikipedia. 2020. Cangkrep Kidul, Purworejo, Purworejo. Online at https://id.wikipedia.org/ [diakses 07 Maret 2020, pukul 18.15]. 